\title{
В.Л. ШЕВЧИК
}

Канівський природний заповідник ННЦ «Інституту біології» Київського національного університету

імені Тараса Шевченка

вул. Шевченка, м. Канів, 108, Україна

shewol@ukr.net

\section{SCROPHULARIA VERNALIS (SCROPHULARIACEAE) В КАНIВCЬКОМУ ПРИРОДНОМУ ЗАПОВІДНИКУ}

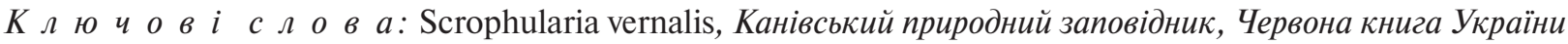

Заходи з охорони певного виду рослин мають передбачати дослідження його біології, особливостей структури популяцій, репродукційного процесу в конкретних місцезростаннях і регіонах. Визначення статусу «вразливий» і вказівки про недостатнє вивчення структури популяцій і відсутність досвіду з розведення Scrophularia vernalis L. (Червона..., 2009) на території України робить цей вид актуальним об'єктом дослідження у вищевказаних напрямах. Scrophularia vernalis занесена до списків охоронюваних видів Кіровоградської та Донецької областей. Для Дніпропетровської обл. вид наводиться як такий, що може належати до однієї з категорій - «зникаючі», «вразливі» чи «рідкісні», - але ще не занесений до неї через відсутність інформації (Офіційні..., 2012).

Scrophularia vernalis - широколистяно-лісовий вид, належить до західноєвропейського геоелемента, види якого ірадіюють на схід від Дніпра; він має також низку вікарних споріднених видів у Південно-Західній Азії (Клеопов, 1990). На території України наразі відомо більше 30 його місцезростань, приурочених переважно до лівобережної частини Лісостепу (Червона..., 2009). За ставленням до різних абіотичних чинників вид має досить широкий екологічний діапазон, зокрема: за термокліматом він характеризується від суббореального (7 балів) до субсередземноморського (11 балів); за континентальністю - від океанічного до континентального (3-13); за омброкліматом - від мезоаридного (5) до гумідного (11); за кріокліматом - від помірних (7) до теплих і дуже теплих зим (12); за вологістю грунту - від сухолісолучних (11) до сиролісолучних (15); за кислотностю грунту від кислих (5) до слаболужних (11); за багатством грунту на азот - від бідних (4) до багатих і надмірно багатих на азот грунтів (11); за освітленням - від узлісних (2) до тінисто-лісових (8) (Цыганов, 1983).

( В В.Л. ШЕВЧИК, 2013
На території Канівського заповідника S. vernalis уперше був виявлений 15.05.1992 р. неподалік від постійної пробної ділянки № 7 (Літопис ..., 1993). Ми зробили геоботанічні описи тих ділянок, де він зростає. УПродовж кількох років (1993-1994 та 2009-2013) стежили за його розвитком у природних умовах. Під час спостережень робили обліки окремих морфопараметрів, а потім обробляли отримані дані. Здійснювали також експериментальні дослідження особливостей насіннєвого поновлення виду; зокрема, зробили спробу штучно відтворити його нові популяції у природних фітоценозах насіннєвим способом.

Уперше описуючи ділянку розміром у кілька квадратних метрів, відзначили, що серед грабового лісу «нагірної» частини заповідника зростає п'ять особин S. vernalis, які мають по 5-10 квіток. У деревостані найбільше поширений (проективне покриття до 50 \%) Carpinus betulus L. Iз покриттям близько $10 \%$ зростають Acer platanoides L., A. campestre L., Fraxinus excelsior L., Ulmus glabra Huds. Підлісок сформований лише підростом A. platanoides. Покриття трав'яного ярусу становить близько $90 \%$. Весною домінують ефемероїди та геміефемероїди, зокрема Corydalis solida (L.) Clairv., C. cava (L.) Schweigg. \& Körte, Anemone ranunculoides L., Dentaria bulbifera L., Allium ursinum L. Серед рослин, які вегетують улітку i взимку, залишається зеленою висока чисельність особин Carex pilosa Scop., Lamium galeobdolon (L.) L., L. maculatum (L.) L., Glechoma hirsuta Waldst. \& Kit., Galium odoratum (L.) Scop., Asarum europaeum L., Stellaria holostea L., Cystopteris fragilis (L.) Bernh., Dryopteris filix-mas (L.) Schott.

У зв'язку з відсутністю низки морфологічних характеристик регіональних морфотипів цього виду в літературі наводимо деякі з них, визначені на основі результатів власного обстеження зразків рослини в польових і лабораторних умовах для даного фенологічного стану. Довжина черешків 
листків змінюється від 0,5 (верхні листки) до 7 см (нижні листки). Верхня частина листка тупо заокруглена, нижня серцеподібно-округла. Найбільші за розмірами листки мали довжину 11 , ширину 10 см. Стебло чітко чотиригранне, опушене звивистими волосками різної довжини. На коротких прямих волосках черешків, чашолистиків і стебел розміщені залозки. Залозисте опушення нижньої частини стебла сховане під густим покривом звивистих волосків. Насінини яйцеподібно-вигнутої форми, валикувато-ребристі (до 7-8 опуклих, поперечно-морщинистих у сухому стані валиківребер). Довжина насінини 1,0-1,3 мм, ширина 0,5-0,7 мм.

У 1993 р. (01.06.) ми спостерігали збільшення кількості особин у вказаній локальній популяції. На окремих ділянках було до 25 сіянців на $1 \mathrm{~m}^{2}$. Вони мали здебільшого дисперсно-груповий характер розміщення. Окремі з них поодиноко траплялися на відстані кількох метрів від місцезнаходження тих особин, за якими ми спостерігали минулого року. Очевидна залежність ефективності проростання насіння від стану поверхні грунту. Всі сіянці приурочені до мікростацій із рихлим грунтом без лісової підстилки. Під час обстеження вказаної ділянки 12.04.1994 р. ми виявили лише поодинокі особини. Більшість минулорічних сіянців загинула. 09.06.1994 р. пагони перебували наприкінці фази цвітіння. У наступні два роки на даній ділянці особин досліджуваного виду не виявили.

Після виходу у світ третього видання «Червоної книги України» (2009) ми поновили спостереження за $S$. vernalis у вказаному локалітеті. Пошуки його особин на місці попереднього їх виявлення навесні 2010 та 2011 років результатів не дали. Повторно обстеживши територію восени 2011 р., ми знайшли лише одну особину. Це - сіянець першого року розвитку. Місце його зростання було помічене для подальших спостережень. За даною особиною, знайденою восени 2011 р., ми спостерігали впродовж вегетаційного періоду 2012 р. На початку квітня (02.04.2012р.) в рослини було одиночне стебло заввишки 7 см із двома минулорічними (зимуючими) та шістьма молодими листками цьогорічного приросту. 24.04.2012 р. рослина мала стебло заввишки 30 см із сімома парами листків, перебувала у фазі кінця бутонізації та початку цвітіння. Найнижчі квітконоси розміщені в пазухах п’ятої пари листків. Цвітіння рослини повністю припинилося 14.05.2012 р. Стебло мало висоту 64 см, 10 пар листків, 16 суцвіть і 71 зав'язь. Листки розетки повністю відмерли. Насіння перебувало у стадії молочно-воскової стиглості й було світлозеленого кольору. 28.05.2012 р. спостерігалася фаза початку дозрівання центральних коробочок. Було взято кілька з них для висівання насіння ex situ. 01.10.2012 р. стебло повністю відмерло, всі коробочки були розкриті й майже без насіння. Сіянці поблизу стебла не виявлені. Зібране 06.06.12 р. насіння висіяли ex situ. Шість штук розсади, отриманих у лабораторних умовах, висадили в 17 кварталі, 77 виділі. У жовтні 2012 р. ми відзначили, що повністю прижилися та добре розвивалися п'ять особин. Починаючи з весни 2013 р. всі п’ять піддослідних особин розвивалися нормально. 30.04.2013 p. найбільша з рослин мала висоту 25 см і перебувала у фазі бутонізації. 18.06. 2013 р. середні показники основних морфопараметрів усіх особин становили: висота стебла (в см) - 56,5 $\pm 13,98$; кількість

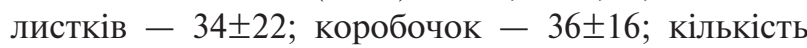
розгалужень стебла $-2 \pm 3$. Упродовж вегетаційного періоду 2013 р. ми тричі збирали незначну кількість насіння для експериментального дослідження особливостей насіннєвого відновлення. Насіння висівали в стаканчики, наповнені лісовим грунтом на суглинистій основі, без загортання. Регулярно поливали посіви способом розпилювання води й не допускали пересихання поверхні грунту. Висіяне 18.06. 2013 р. свіжозібране насіння (115 шт.) упродовж літа дало три порції проростків. Перші чотири проростки з'явилися 29.06.2013 р., наступні (14 шт.) - 07.07.2013 р., останні (2 шт.) 13. 08.2013 р. Посіви насіння пізніших зборів (09.07 та 21.08.2013) за аналогічного догляду впродовж літа 2013 р. сходів не дали. Отриманий посадковий матеріал висаджено в природні фітоценози Канівського заповідника для подальших спостережень.

Виходячи з вищевикладеного, можна зробити висновок, що $S$. vernalis за життєвою стратегією слід вважати видом-експлерентом синузії озимих малорічників трав'янистого ярусу широколистяних лісів, для популяцій якого характерні періодичні збільшення та зменшення чисельності особин, що визначаються чергуванням сприятливих i несприятливих для виживання його сіянців періодів. Основний механізм підтримання чисельності особин у його локальних популяціях - здатність окремих фракцій насіння тривалий час зберігати 
схожість, а також гетероспермні властивості цього виду, порційність проростання насіння впродовж вегетаційних періодів кількох років, що забезпечує ймовірність виживання сходів і перебіг повного онтогенетичного циклу лише в окремі фенологічно сприятливі роки.

\section{СПИСОК ЛІТЕРАТУРИ}

1. Клеопов Ю.Д. Анализ флоры широколиственных лесов европейской части СССР. - Киев: Наук. думка, 1990. $352 \mathrm{c}$.

2. Літопис природи Канівського природного заповідника за 1992 рік (На правах рукопису). Книга XXY. - Канів, 1993. - 182 c.

3. Офіційні переліки регіонально рідкісних рослин адміністративних територій України (довідкове видання) / Укладачі: Т.Л. Андрієнко, М.М. Перегрим. К.: Альтерпрес, 2012. - 148 с.

4. Червона книга України. Рослинний світ / За ред. Я.П. Дідуха. - К.: Глобалконсалтинг, 2009. - 900 с.

5. Цыганов Д.Н. Фитоиндикация экологических режимов в подзоне хвойно-широколиственных лесов. - М.: Наука, 1983. - 197 с.

Рекомендує до друку

Надійшла 07.11.2013 p.

М.М. Федорончук

\section{В.Л. Шевчик}

Каневский природный заповедник НУЦ «Института биологии» Киевского национального университета имени Тараса Шевченко

SCROPHULARIA VERNALIS (SCROPHULARIACEAE) В КАНЕВСКОМ ПРИРОДНОМ ЗАПОВЕДНИКЕ

Описано новое местонахождение Scrophularia vernalis L. (Scrophulariaceae) на территории Каневского природного заповедника. Дана его фитоценотическая характеристика. Проанализированы и обобщены результаты наблюдений за некоторыми морфометрическими характеристиками и особенностями репродукции вида.

Ключ и в ы е слов в: Scrophularia vernalis, Каневский природный заповедник, Красная книга Украины.

V.L. Shevchyk

Kaniv Nature Reserve of the Scientific Centre «Institute of Biology», Taras Shevchenko National University of Kyiv

SCROPHULARIA VERNALIS (SCROPHULARIACEAE) IN KANIV NATURE RESERVE

A new record of Scrophularia vernalis L. (Scrophulariaceae) from Kaniv Nature Reserve is reported. Cenotic characteristics of the species habitat are described. Based on the original data, some morphometric characteristics and reproduction features are analyzed and summarized.

K e y w o r d s : Scrophularia vernalis, Kaniv Nature Reserve, Red Data Book of Ukraine. 